\title{
Water Saturation Stress in Mimosa scabrella Seedlings
}

\author{
Eduarda Demari Avrella ${ }^{1}$ (D), João Miguel Weber ${ }^{1}$ (D), Claudimar Sidnei Fior ${ }^{1}$ \\ ${ }^{1}$ Departamento de Horticultura e Silvicultura, Universidade Federal do Rio Grande do Sul - UFRGS, \\ Porto Alegre/RS, Brasil
}

\begin{abstract}
The stress caused by water saturation has negative consequences for plants. The search for species tolerant to flooded soils can make feasible the use of areas with these characteristics. The objective of this study was to observe the effect of water saturation levels on the initial growth of Mimosa scabrella Benth seedlings. Newly germinated seedlings were subjected to three water depths (without saturation, $1 / 3$, and $2 / 3$ above the pot capacity) in a greenhouse environment. After 173 days, it was verified that for most of the variables there was no difference between the control treatment and the two saturation levels. In addition, the analysis of seedling quality demonstrated the ability of the species to develop and survive in this condition. Therefore, it is inferred that bracatinga is a promising species for cultivation under water saturation conditions.
\end{abstract}

Keywords: restoration/recovery/rehabilitation of areas, forestry, afforestation and reforestation. 


\section{INTRODUCTION}

Mimosa scabrella Benth. (Fabaceae) is a tree species, popularly known as bracatinga, with a height of 10 to 18 meters, and 20 to 30 centimeters of $\mathrm{DBH}$ (diameter at breast height $-1.30 \mathrm{~m}$ ), being able to reach from 20 to $30 \mathrm{~m}$ in height and 40 to $50 \mathrm{~cm}$ in $\mathrm{DBH}$ after eight years old, when a vital decline is common (Fabrowski et al., 2005). It is a perennial, heliophyte and pioneer plant (Saueressig, 2014), which occurs mainly in secondary formations of the Mixed Ombrophilous Forest, where it forms almost pure dense nuclei (Rotta \& Oliveira, 1981). In addition to its several economic and environmental potentialities, the species also occurs in riparian forests (Brunetto et al., 2004) and is indicated for the recovery of degraded areas (Saueressig, 2014), some of which are riparian and subject to periodic flooding (Medri et al., 2012).

The vegetation of the riparian environment maintains the integrity and stability of the hydrographic microbasin. Thus, the preservation and restoration of forests along rivers and around lakes and reservoirs is essential (Bassaco, 2011). Since riparian forests are associated with watercourses, they undergo periodic flooding, which may be a stressor for the development of many plant species (Grisi et al., 2011).

Excess soil water results in unsatisfactory drainage, leading to reduced oxygen availability to the cells, where flood-sensitive plants are heavily damaged. At low oxygen concentrations, respiration rates decrease, leading to reduced ATP production, and an inability to perform biochemical processes, and ultimately to cell death (Voesenek et al., 2006). Moreover, with oxygen deficiency in the soil, anaerobic organisms create an extremely reductive medium, in which $\mathrm{Fe}^{2+}, \mathrm{Mn}^{2+}$, $\mathrm{H}_{2} \mathrm{~S}$, sulfites, lactic acid, among others, are toxic, as well as the nitrogen replacement under these edaphic conditions becomes noticeably limited (Colmer \& Voesenek, 2009).

The excess water can lead to several potentially negative consequences for a plant, decreasing root and shoot growth (Jackson \& Colmer, 2005). Furthermore, there might be changes in carbon assimilation, macronutrient uptake, and suppression of the respiratory metabolism of roots (Kozlowski, 1997). Nevertheless, there might also be metabolic alterations such as reduced energy consumption, activation of anaerobic routes, and less investment in growth. The stomatal closure and the decrease of photosynthesis are also changes that occur due to flood-related oxygen deficiency in the soil (Almeida \& Valle, 2007; Rehem et al., 2009).

However, water saturation does not completely prevent the occurrence of some physiological processes, since, even in flooding, some species are photosynthetically active, while others may continue to grow and develop during stress caused by excess water (Schöngart et al., 2002). Many plants germinate, emit roots, and grow on oxygen deficient soils since they present adaptations that enable them to overcome and develop in these environments (Jackson \& Colmer, 2005).

The stress caused by water saturation has a strongly selective character, because during the evolutionary process, tolerant species developed a variety of strategies that promoted their development in flooded environments (Blokhina et al., 2003; Gibbs \& Greenway, 2003; Colmer \& Voesenek, 2009). Hence, knowledge about the resistance or tolerance of species to water saturation is of great importance, since it allows their use in areas close to watercourses or that present surface water table, since non-tolerant plants show growth below the desired or do not survive under these conditions (Casemiro et al., 2008).

Studies on the growth and development of species capable of adapting to water stress conditions caused by excess water can play a key role in understanding the strategies developed by plants to survive and grow under these conditions (Costa et al., 2006). Thus, despite the great economic and environmental importance of bracatinga, information on the responses of plants under water saturation conditions is still scarce. Therefore, aiming to contribute to the knowledge about the use of bracatinga in riparian forest recovery programs and to provide information on plant responses to this ecological condition, the objective of this study was to verify the effect of different levels of water saturation of the substrate on the development of Mimosa scabrella Benth seedlings.

\section{MATERIALS AND METHODS}

The present study was carried out in a greenhouse belonging to the Department of Horticulture and Forestry of the Federal University of Rio Grande do Sul, in Porto Alegre, RS, from December 2014 to May 2015. 
The seeds were collected from eight matrices, in the municipality of Santo Antônio do Palma, RS, in December 2012 (exsicata registered in the UFRGS herbarium, ICN 184890), and they were stored in a refrigerator at $5{ }^{\circ} \mathrm{C}$.

The seeds were subjected to dormancy-breaking by the method of immersion in hot water $\left(90^{\circ} \mathrm{C}\right)$ until reaching room temperature, which was determined in a pilot study as being the most practical and fast method for breaking the dormancy of bracatinga seeds. Afterward, they were sown in expanded polystyrene trays containing substrate based on coconut fiber (Golden Mix type $\mathrm{PM}^{\bullet}$ - AMAFIBRA), and three seeds per cell were established. When the seedlings reached approximately $5 \mathrm{~cm}$ in height, thinning was performed leaving only the most vigorous one. After 66 days, the seedlings were transplanted to 2.8 - $\mathrm{L}$ pots containing composted pine bark as substrate, whose main chemical and physical characteristics are presented in Table 1.

The treatments were defined by three water depths, in which the control treatment was based on the pot capacity, determined through analysis in the Laboratory of Analysis of Substrates of the Department of Horticulture and Forestry of the Faculty of Agronomy, UFRGS. Thus, the irrigations were tested corresponding to no saturation (control - 100\% pot capacity), $1 / 3$, and $2 / 3$ pot saturation.

The pots of the treatment without saturation had a dish with a height of $1.5 \mathrm{~cm}$ at their bottom, which remained with water to ensure complete hydration of the substrate by capillarity, at full time. For the treatment with saturation of $1 / 3$ of the pot height, a transparent polyethylene bag was used inside the pot containing the substrate. In that, drainage holes were

Table 1. Chemical and physical properties of the composted pine bark substrate used in the experiment.

\begin{tabular}{|c|c|}
\hline \multicolumn{2}{|c|}{ Chemical properties } \\
\hline CE $1: 5\left(\mathrm{mS} \mathrm{cm}^{-1}\right)$ & 0.51 \\
\hline $\mathrm{pH}\left(\mathrm{H}_{2} \mathrm{O}\right)$ & 6.69 \\
\hline \multicolumn{2}{|c|}{ Physical properties } \\
\hline Dry density $\left(\mathrm{Kg} \mathrm{m}^{-3}\right)$ & 438.90 \\
\hline Total porosity (\%) & 64.70 \\
\hline Aeration space (\%) & 20.23 \\
\hline Easily available water (\%) & 10.31 \\
\hline Buffering water (\%) & 1.66 \\
\hline Remaining water (\%) & 32.50 \\
\hline
\end{tabular}

made at a height corresponding to $1 / 3$ of the pot from the base. Thus, the basal third of the pot containing the substrate and the plant remained saturated at full time. This procedure was also performed with the treatment pots with $2 / 3$ saturation of the pot height, except that the drainage holes were made to two-thirds the pot height from the base.

Substrate irrigation was performed daily to keep the plants in full-time water saturation, applying a uniform water depth in all treatments, with a drainage volume of less than $20 \%$ of the total applied. Fertilization was carried out at 48, 90, and 126 days after starting the experiment, by incorporating approximately $2.8 \mathrm{~g} / \mathrm{L}$ of a base fertilization composed of NPK granulated fertilizer to the substrate, formulation 7:11:9.

The evaluations were performed every 30 days for the variables plant height and neck diameter. Plant height was obtained by a millimeter ruler, measured from the plant neck to the apical bud; neck diameter was measured with a digital caliper. After 173 days of conduction of the experiment, the following variables were evaluated: fresh and dry mass of shoots and roots, total root volume, plant height, and neck diameter. Based on these data, the quality of the seedlings was also evaluated from the Dickson Quality Index (DQI), besides to the height and neck diameter ratio (H/ND), the height and dry mass of shoots ratio (H/DMS), and the dry mass of shoots and dry mass of roots ratio (DMS/DMR), according to Gomes \& Paiva (2013).

The experimental design was completely randomized, with four replicates of five plants per treatment, totaling 12 experimental units. Data were submitted to analysis of variance (ANOVA) by the software Costat 6.4, orthogonal contrasts by SAS 9.4, and polynomial regression by SigmaPlot 11.0. Since the data of fresh mass of shoots did not meet the assumptions of the analysis of variance, they were transformed to $\sqrt{\mathrm{x}}$.

\section{RESULTS AND DISCUSSION}

The statistical analysis of the data showed no influence of the different levels of water saturation on the variables shoot height, total root volume, height and neck diameter ratio, and dry mass of shoots and dry mass of roots ratio. However, there was a significant difference in neck diameter, fresh and dry mass of 
shoots, fresh and dry mass of roots, height and dry mass of shoots ratio, and Dickson quality index (Table 2).

The different levels of water saturation showed an influence since, from the analysis of the orthogonal contrasts, there was a decrease in plant growth with increased water saturation. However, except for the variables fresh and dry mass of shoots, and height

Table 2. Analysis of variance of the growth and initial development of bracatinga (Mimosa scabrella Benth.) seedlings as a function of different levels of water saturation in the substrate, at 173 days after the installation of the experiment.

\begin{tabular}{|c|c|c|c|c|}
\hline & $\begin{array}{l}\text { Hydric } \\
\text { regime }\end{array}$ & Average & CV (\%) & GL \\
\hline Height $(\mathrm{cm})$ & $\mathrm{p}=0.426^{\mathrm{ns}}$ & 122.04 & 10.10 & 9 \\
\hline $\begin{array}{l}\text { Neck diameter } \\
(\mathrm{mm})\end{array}$ & $\mathrm{p}<0.01$ & 9.02 & 6.08 & 9 \\
\hline FMS (g) & $\mathrm{p}<0.01$ & 9.37 & 6.57 & 9 \\
\hline DMS (g) & $\mathrm{p}<0.01$ & 21.53 & 15.39 & 9 \\
\hline FMR (g) & $\mathrm{p}<0.01$ & 172.73 & 18.83 & 9 \\
\hline DMR (g) & $\mathrm{p}<0.01$ & 21.38 & 19.19 & 9 \\
\hline $\begin{array}{l}\text { Root volume } \\
(\mathrm{mL})\end{array}$ & $\mathrm{p}=0.085^{\mathrm{ns}}$ & 211.33 & 24.95 & 9 \\
\hline $\mathrm{H} / \mathrm{ND}$ & $\mathrm{p}=0.348^{\mathrm{ns}}$ & 13.65 & 11.85 & 9 \\
\hline H/DMS & $\mathrm{p}<0.01$ & 7.76 & 20.27 & 9 \\
\hline DMS/DMR & $\mathrm{p}=0.523^{\mathrm{ns}}$ & 1.26 & 34.20 & 9 \\
\hline DQI & $\mathrm{p}=0.02$ & 3.35 & 24.97 & 9 \\
\hline
\end{tabular}

ns non significant at $5 \%$ error probability; $\mathrm{ND}=$ neck diameter; FMS $=$ fresh mass of shoots; DMS $=$ dry mass of shoots; FMR = fresh mass of roots; DMR = dry mass of roots; $\mathrm{H} / \mathrm{ND}=$ height and neck diameter ratio; H/DMS = height and dry mass of shoots ratio; DMS/DMR = dry mass of shoots and dry mass of roots ratio; DQI = Dickson Quality Index; $\mathrm{CV}=$ coeficiente of variation; $\mathrm{GL}=$ degrees of freedom. and dry mass of shoots ratio, there was no significant difference between the control treatment and the water saturation levels (Table 3 ).

The height of the bracatinga seedlings showed no difference as a function of the water saturation levels, which may indicate a certain degree of tolerance of this species to flooding, since the plants subjected to water saturation did not show any injury or growth impairment when compared to the plants of the control treatment (without saturation).

For the neck diameter, there was no significant difference between the control treatment and the water saturation levels, but there was a difference between the two saturation levels. The highest mean was observed in the treatment with $1 / 3$ pot saturation $(9.69 \mathrm{~mm})$, followed by the control treatment $(9.47 \mathrm{~mm})$, and $2 / 3$ pot saturation $(7.91 \mathrm{~mm})$. Similar results were observed for Schizolobium parahyba, where seedlings subjected to water saturation in running water showed a decrease in the neck diameter (Costa et al., 2006). However, for Aegiphila sellowiana, flooding did not affect the neck diameter (Medri et al., 2012).

Reduced plant development under high water saturation can be explained by the lower availability of energy caused by hypoxia (reduction of oxygen supply to cells), since under these conditions, the plants tend to divert metabolism to fermentative pathways, which results in a decrease in ATP production (Colmer \& Voesenek, 2009; Taiz \& Zeiger, 2013). Furthermore, photosynthesis is severely restricted due to carbon dioxide deficiency (Jackson \& Colmer, 2005), partial

Table 3. Analysis of orthogonal contrasts of the growth and initial development of bracatinga (Mimosa scabrella Benth.) seedlings as a function of different levels of water saturation in the substrate, at 173 days after the installation of the experiment.

\begin{tabular}{|c|c|c|c|c|c|}
\hline & \multicolumn{3}{|c|}{ Average } & \multicolumn{2}{|c|}{ Orthogonal contrasts } \\
\hline & Without saturation & $1 / 3$ & $2 / 3$ & C1 & $\mathrm{C} 2$ \\
\hline $\mathrm{ND}(\mathrm{mm})$ & 9.47 & 9.69 & 7.91 & $\mathrm{p}=0.077^{\mathrm{ns}}$ & $\mathrm{p}<0.01$ \\
\hline FMS (g) & 99.40 & 96.49 & 69.81 & $\mathrm{p}=0.050$ & $\mathrm{p}<0.01$ \\
\hline DMS (g) & 24.70 & 23.98 & 15.92 & $\mathrm{p}=0.044$ & $\mathrm{p}<0.01$ \\
\hline FMR (g) & 188.99 & 212.80 & 116.38 & $\mathrm{p}=0.252^{\mathrm{ns}}$ & $\mathrm{p}<0.01$ \\
\hline DMR (g) & 21.54 & 27.34 & 15.25 & $\mathrm{p}=0.926^{\mathrm{ns}}$ & $\mathrm{p}<0.01$ \\
\hline H/DMS & 5.56 & 6.33 & 11.40 & $\mathrm{p}<0.01$ & $\mathrm{p}<0.01$ \\
\hline DQI & 3.81 & 4.08 & 2.15 & $\mathrm{p}=0.209^{\mathrm{ns}}$ & $\mathrm{p}<0.01$ \\
\hline
\end{tabular}

${ }^{\text {ns }}$ non significant at $5 \%$ error probability; $\mathrm{Cl}=$ orthogonal contrast between the control treatment and the water saturation levels; $\mathrm{C} 2=$ orthogonal contrast between the two levels of water saturation $(1 / 3$ and $2 / 3)$; ND = neck diameter; FMS = fresh mass of shoots DMS = dry mass of shoots; FMR = fresh mass of roots; DMR = dry mass of roots; H/DMS = height and dry mass of shoots ratio; DQI = Dickson Quality Index. 
stomatal closure, and increased ethylene production, which may cause chlorosis and premature senescence of leaf tissues, leading to a decrease in photosynthetic rate (Chen et al., 2005).

The growth of the bracatinga seedlings in height and neck diameter throughout the conduction time of the experiment presented linear increase for all saturation levels (without saturation, $1 / 3$, and $2 / 3$ ) (Figure $1 \mathrm{~A}$ and $\mathrm{B}$ ). For the two variables, the lowest values were observed in plants subjected to the highest level of water saturation when compared to the control treatment and $1 / 3$ pot saturation.

The results of fresh and dry mass of shoots showed a significant difference between the saturation levels, as well as between them and the control treatment, where there was a decrease of 2.93 and $29.77 \%$ in the fresh mass and of 2.92 and $35.56 \%$ in the dry mass of shoots, for treatments $1 / 3$ and $2 / 3$, respectively. This can be related to the reduction in the oxygen availability to the cells, caused by the unsatisfactory drainage in soils with excess water (Voesenek et al., 2006). Therefore, ethylene and ethylene precursors are formed in large amounts, inducing stomatal closure in the leaves and usually foliar abscission, reducing the photosynthetic rate (Chen et al., 2005), resulting in decreased the growth and the development of plants.

This reduction in plant growth should not be interpreted as intolerance to flooding, since it may be related to a stress tolerance strategy generated by water saturation. Most of the flood-tolerant species present a significant general reduction in growth, in addition to reduced root growth, which can lead to energy savings (Medri et al., 2012). This result was also observed in Theobroma cacao, which showed a decrease in both the photosynthetic rate and the leaf area, resulting in reduced carbon and biomass absorption in flooded plants (Rehem et al., 2009).

Regardin to the root system of the bracatinga seedlings subjected to water saturation, there was a difference between the two water depths, in which the increase in water saturation promoted less root development. However, Medri et al. (2011) verified that root or stem tissues from Aegiphila sellowiana plants grown in flooded soil have lower density, which is a result of larger and more vacuolated cells and many intercellular spaces, constituting an adaptation of the plants to flooding situations.

Another adaptation may be related to structural barriers composed of suberized and lignified cell walls that prevent the diffusion of oxygen towards the ground. Thus, this retained oxygen supplies the apical meristem and allows the growth to extend towards the anaerobic soil (Taiz \& Zeiger, 2013). Furthermore, aerenchyma formation allows the storage and distribution of oxygen to the tissues, favoring aerobic respiration under soil water saturation conditions (Voesenek et al., 2006; Medri et al., 2007). This information highlights the possibility of using bracatinga in situations of water saturation, since besides the fact that the total volume of roots did not present a significant difference between the treatments, for the dry and fresh mass of roots,
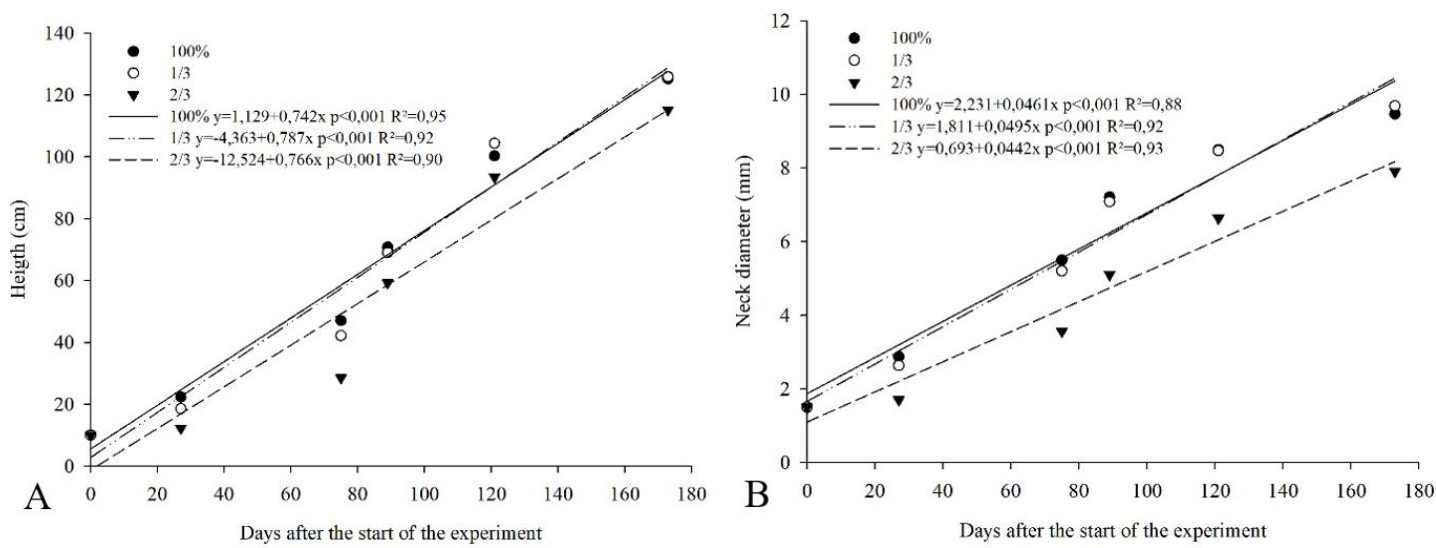

Figure 1. Height (A) and neck diameter (B) of bracatinga (Mimosa scabrella Benth.) seedlings throughout the conduction time of the experiment. 
there was also no difference between the two levels of water saturation and the treatment without saturation.

The analysis of the quality standard of seedlings is of extreme importance since it is directly related to the survival, establishment, and initial growth of the plants. Among the parameters that determine seedling quality, the height and neck diameter ratio expresses a growth balance and it is considered one of the most accurate for providing information on how thin the seedling is (Gomes \& Paiva, 2013). The results of the present study showed that there was no influence of the water saturation levels on this variable, that is, there was no difference between the control treatment and the two saturation levels ( $1 / 3$ and $2 / 3)$, indicating that the quality of the seedlings was not hampered by these conditions.

The dry mass of shoots and dry mass of roots ratio showed that the shoots of the seedlings presented superiority than the roots. Notwithstanding, there was no significant difference for this ratio between treatments, with no influence of water saturation levels. According to Gomes \& Paiva (2013), the calculated ratio between the dry matter weight of shoots and the respective root system is considered as an efficient and safe index to express the seedling quality, being used for plant growth measurements in ecological and physiological studies. This result reinforces the hypothesis of using bracatinga under conditions of excess water since the quality standard of the seedlings was similar for all saturation levels tested.

The Dickson Quality Index (DQI) is a good indicator of the quality of seedlings since it considers the robustness and the balance of the seedling biomass distribution, including several parameters considered important (Gomes \& Paiva, 2013). The results obtained for the bracatinga seedlings showed no significant difference between the control treatment and the saturation levels, but there was a difference between the saturation levels tested. In this sense, the highest mean value was 4.08 in treatment $1 / 3$, decreasing to 2.15 in $2 / 3$. Based on research regarding this index, the minimum value of 0.20 is recommended as a good indicator for the quality of seedlings of Pseudotsuga menziessi and Picea abies (Gomes \& Paiva, 2013).

The quotient obtained by dividing the plant height by the dry mass of shoots is of great value to predict the survival potential of the seedling in the field, and the lower this index, the more lignified will be the seedling and the greater its capacity of survival in the field (Gomes \& Paiva, 2013). The results of this study showed a significant difference between the control treatment and the two levels of water saturation, as well as between these levels. The averages of treatments without saturation and with $1 / 3$ saturation presented similar results (5.56 and 6.33, respectively), demonstrating that water saturation at $30 \%$ above pot capacity presented satisfactory results.

The results of this study did not show a severe effect of water saturation on plant survival, since in general, there was only $5.83 \%$ mortality. These results were not verified for Aegiphila sellowiana (Medri et al., 2012) and Schizolobium parahyba (Costa et al., 2006), which presented high levels of mortality under water saturation conditions ( 33.30 and $44.95 \%$, respectively). According to Costa et al. (2006), the high mortality rate of plants subjected to flooding suggests that they have difficulty to tolerate flood, which was not verified in this study, reinforcing the hypothesis that bracatinga is a promising species to it use in areas with excess water.

Soil flooding reduces the availability of oxygen to plants. However, some species can alter their morphoanatomy allowing the diffusion of oxygen from the shoots to the roots, which maintains aerobic respiration. These modifications include the formation of aerenchyma, adventitious roots, lenticels, among others, which are important for the survival of plants in a flooded environment (Almeida \& Valle, 2007; Grisi et al., 2011). These changes were observed in Lithraea molleoides, where there was a reduction in the allocation of growth resources that were used in the production of morphological alterations, such as hypertrophied lenticels and increased intercellular spaces, contributing to the survival of the plants during the period of stress (Medri et al., 2007)

In this way, it is necessary to study whether bracatinga plants present these morpho-anatomical changes, to verify if the satisfactory results obtained in this study are related to morphological alterations in the plants. Also, future work must be also considered the genetics, since the genetic diversity within the species can influence the tolerance to water saturation stress.

The establishment phase of the plants is fundamental and decisive in their development since when they are able to complete this phase, they will be able 
to compete successfully in the subsequent phases (Navroski et al., 2016). Hence, the results obtained in the present study support the hypothesis that bracatinga (Mimosa scabrella Benth.) has a set of characteristics that allow its use in the recovery of vegetation in riparian areas, being able to generate forest products and services, besides optimizing the land use in rural properties in southern Brazil, since the low development of some variables can be seen as a way of saving energy and survival.

\section{CONCLUSIONS}

Bracatinga is a promising species for the cultivation under water saturation conditions since there was no decline in seedling growth when under intermediate saturation conditions (1/3 pot saturation), whereas, there was low interference in higher saturation situations (2/3 pot saturation).

\section{SUBMISSION STATUS}

Received: 11 may, 2016

Accepted: 22 dec., 2017

\section{CORRESPONDENCE TO}

\section{Eduarda Demari Avrella}

Programa de Pós-graduação em Fitotecnia, Departamento de Horticultura e Silvicultura, Faculdade de Agronomia, Universidade Federal do Rio Grande do Sul - UFRGS, Bento Gonçalves, 7712, CEP 91540-000, Porto Alegre, RS, Brasil e-mail: dudademari@hotmail.com

\section{FINANCIAL SUPPORT}

Coordenação de Aperfeiçoamento de Pessoal de Nível Superior, (CAPES). Fundação de Amparo à Pesquisa do Estado do Rio Grande do Sul, (FAPERGS).

\section{REFERENCES}

Almeida AAF, Valle RR. Ecophysiology of the cacao tree. Brazilian Journal of Plant Physiology 2007; 19(4): 425-448. http://dx.doi.org/10.1590/S1677-04202007000400011.
Bassaco MVM. Comportamento fenológico, germinação, produção de mudas e tolerância a saturação hídrica de Sebastiania brasiliensis (Spreng.) [dissertação]. Curitiba: Universidade Federal do Paraná; 2011.

Blokhina O, Virolainen E, Fagerstedt KV. Antioxidants, oxidative damage and oxygen deprivation stress: a review. Annals of Botany 2003; 91(Spec No): 179-194. http://dx.doi. org/10.1093/aob/mcf118. PMid:12509339.

Brunetto RS, Belotti A, Sobral LS, Gottardi E. Estrutura florística e fitossociológica de remanescentes da mata ciliar do lajeado São José - Chapecó (SC). UNOPAR Científica. Ciências Biológicas e da Saúde 2004; 5(6): 69-76.

Casemiro ELN, Malavasi UC, Malavasi MM. Efeitos da saturação hídrica, idade e volume radicular no crescimento inicial de quatro espécies florestais. Floresta e Ambiente 2008; 15(1): 13-19.

Chen H, Qualls RG, Blank RR. Effect of soil flooding on photosynthesis, carbohydrate partitioning and nutrient uptake in the invasive exotic Lepidium latifolium. Aquatic Botany 2005; 82(4): 250-268. http://dx.doi.org/10.1016/j. aquabot.2005.02.013.

Colmer TD, Voesenek LACJ. Flooding tolerance: suites of plants traits in variable environments. Functional Plant Biology 2009; 36(8): 665-681. http://dx.doi.org/10.1071/ FP09144.

Costa AM, Gobbi EL, Demuner VG, Hebling SA. O efeito da inundação so solo sobre o crescimento inicial de Schizolobium parahyba (Vell.) S.F. Blake, guapuruvu. Natureza on line 2006; 4(1):7-13.

Fabrowski FJ, Muñiz GIB, Mazza MCM, Nakashima T, Klock U, Possamai JC et al. Anatomia comparativa da madeira das variedades populares da bracatinga (Mimosa scabrella Bentham). Ciência Florestal 2005; 15(1): 65-73. http://dx.doi.org/10.5902/198050981824.

Gibbs J, Greenway H. Mechanisms of anoxia tolerance in plants. I. Growth, survival and anaerobic catabolism. Functional Plant Biology 2003; 30(1): 1-47. http://dx.doi. org/10.1071/PP98095.

Gomes JM, Paiva HN. Viveiros florestais: propagação sexuada. Viçosa: Editora UFV; 2013.

Grisi FA, Angelo AC, Boeger MRT, Leitão CAE, Galvão SF, Wendling I. Morfoanatomia foliar em mudas de Schinus terebinthifolius sob diferentes níveis de saturação hídrica. Floresta 2011; 41(4): 881-894. http://dx.doi.org/10.5380/ rf.v41i4.25351.

Jackson MB, Colmer TD. Response and adaptation by plants to flooding stress. Annals of Botany 2005; 96(4): 501-505. http://dx.doi.org/10.1093/aob/mci205. PMid:16217870.

Kozlowski TT. Responses of woody plants to flooding and salinity. Tree Physiology Monograph 1997; 1: 1-29.

Medri C, Medri ME, Ruas EA, Souza LA, Medri PS, Sayhun $\mathrm{S}$ et al. Morfoanatomia de órgãos vegetativos de plantas juvenis de Aegiphila sellowiana Cham. (Lamiaceae) 
submetidas ao alagamento do substrato. Acta Botanica Brasílica 2011; 25(2): 445-454. http://dx.doi.org/10.1590/ S0102-33062011000200020.

Medri C, Pimenta JA, Ruas EA, Souza LA, Medri PS, Sayhun $\mathrm{S}$ et al. O alagamento do solo afeta a sobrevivência, o crescimento e o metabolismo de Aegiphila sellowiana Cham. (Lamiaceae)? Semina. Ciências Biológicas e da Saúde 2012; 33(1): 123-134. http://dx.doi.org/10.5433/1679$0367.2012 \mathrm{v} 33 \mathrm{n} 1 \mathrm{p} 123$.

Medri ME, Ferreira AC, Kolb RM, Bianchini E, Pimenta JA, Davanso-Fabro VM et al. Alterações morfoanatômicass em plantas de Lithraea molleoides (Vell.) Engl. submetidas ao alagamento. Acta Scientiarum. Biological Sciences 2007; 29(1): 15-22. http://dx.doi.org/10.4025/actascibiolsci. v29i1.408.

Navroski MC, Araújo MM, Pereira MO, Fior CS. Influência do polímero hidroretentor nas características do substrato comercial para produção de mudas florestais. Interciencia 2016; 41(5): 357-361.

Rehem BC, Almeida AAF, Mielke MS, Gomes FP. Efeitos do alagamento do substrato no crescimento e na composição química de genótipos clonais de Theobroma cacao L. Revista Brasileira de Fruticultura 2009; 31(3): 805-815. http://dx.doi.org/10.1590/S0100-29452009000300026.

Rotta E, Oliveira YMM. Área de distribuição natural da bracatinga (Mimosa scabrella). In: Anais do IV Seminário sobre atualidades a perspectivas florestais "Bracatinga uma alternativa para reflorestamento"; 1981; Curitiba. Curitiba: Embrapa-URPFCS; 1981, p. 1-24.

Saueressig D. Plantas do Brasil: árvores nativas. 1st ed. Irati: Editora Plantas do Brasil; 2014.

Schöngart J, Piedade MT, Ludwigshausen S, Hornas V, Worbes M. Phenology and stem-growth periodicity of tree species in Amazonian floodplain forests. Journal of Tropical Ecology 2002; 18(04): 581-597. http://dx.doi. org/10.1017/S0266467402002389.

Taiz L, Zeiger E. Fisiologia vegetal. 5th ed. Porto Alegre: Artmed; 2013.

Voesenek LACJ, Colmer TD, Pierik R, Millenaar FF, Peeters AJM. How plants cope wth complete submergence. The New Phytologist 2006; 170(2): 213-226. http://dx.doi. org/10.1111/j.1469-8137.2006.01692.x. PMid:16608449. 